ORISE--97052364

\section{Retrospective Beryllium Exposure Assessment at the Rocky Flats Environmental Technology Site*}

Anthony E. Barnard ${ }^{a}$

Janet Torma-Krajewski ${ }^{a}$

Susan M. Viet ${ }^{\mathrm{b}}$

apepartment of Energy, Rocky Flats Field Office, PO Box 928 Golden, CO 80402; M.H. Chew \& Associates, Inc., PO Box 33, Golden, CO 80402

- The research was performed under appointment to the Industrial Hygiene Graduate Fellowship Program of the U.S. Department of Energy, Office of the Assistant Secretary for Environment, Safety and Health, Industrial Hygiene Programs Division, administered by the Oak Ridge Institute for Science and Education.

\title{
Abstract
}

Since the 1960 's, beryllium machining was performed to make nuclear weapon components at the Department of Energy (DOE) Rocky Flats Plant. Beryllium exposure was assessed via fixed airhead (FAH) sampling in which the filter cassette was affixed to the machine, generally within a few feet of the worker's breathing zone. Approximately 500,000 FAH samples were collected for beryllium over three decades. From 1984 to 1987 , personal breathing zone (PBZ) samples were also collected as part of the evaluation of a new high velocity/low volume local exhaust ventilation (HV/LV LEV) system. The purpose of this study was to determine how the two types of sampling data could be used for an exposure assessment in the beryllium shop.

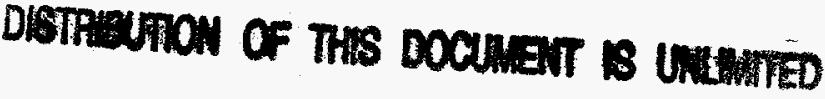

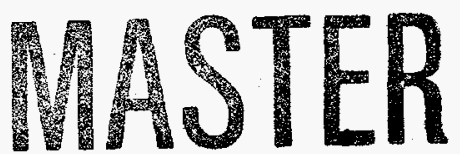




\section{DISCLAIMER}

This report was prepared as an account of work sponsored by an agency of the United States Government. Neither the United States Government nor any agency thereof, nor any of their employees, make any warranty, express or implied, or assumes any legal liability or responsibility for the accuracy, completeness, or usefulness of any information, apparatus, product, or process disclosed, or represents that its use would not infringe privately owned rights. Reference herein to any specific commercial product, process, or service by trade name, trademark, manufacturer, or otherwise does not necessarily constitute or imply its endorsement, recommendation, or favoring by the United States Government or any agency thereof. The views and opinions of authors expressed herein do not necessarily state or reflect those of the United States Government or any agency thereof. 


\section{DISCLAMMIXR}

Portions of this document may be illegible in electronic image products. Images are produced from the best available original document. 
The FAH data indicated that four statistically different exposure periods existed from 1970 to 1988 , as the FAH annual averages correlated with changes in the LEV system and production levels. A matched comparison between the FAH and PBZ sample data found no direct linear correlation $\left(\mathrm{R}^{2}=0.014\right)$; however, the average $\mathrm{PBZ}$ results were higher that the FAH results $(p=0.0001)$. The average PBZ level was $1.04 \mathrm{ug} / \mathrm{m}^{3}$ while the FAH average was $0.16 \mathrm{ug} / \mathrm{m}^{3}$ (PEL for beryllium: $2 \mathrm{ug} / \mathrm{m}^{3}$ ).

A health surveillance program to identify cases of chronic beryllium disease (CBD) and beryllium sensitization has been implemented at Rocky Flats. To date, 53 cases of CBD and 86 cases of sensitivity to beryllium have been diagnosed. Continuing case-control studies are evaluating semi-quantitative dose response relationships for $\mathrm{CBD}$ using the exposure monitoring data discussed herein.

\section{BACKGROUND}

Starting in the late 1950's, beryllium was used at Rocky Flats, now called Rocky Flats Environmental Technology Site (RFETS), to make nuclear weapon components because it is light, strong, and an excellent neutron moderator/reflector. The beryllium was machined into casings for fissionable plutonium atomic weapons components produced at the site. 
In the early 1990 's, the weapons production and beryllium machining at RFETS was discontinued.

The inhalation toxicity of beryllium may occur through acute or chronic exposures. Exposures to high levels of beryllium may cause pulmonary edema and chemical pneumonitis, or may lead to the chronic disease. Chronic beryllium disease (CBD) is a non-caseating granulomatous respiratory disorder caused by an immunological reaction to beryllium exposure. The pathological appearance of CBD is practically indistinguishable from sarcoidosis. Diffuse interstitial fibrosis may occur through the stages of the disease causing restrictive, obstructive and debilitating respiratory manifestations. ${ }^{(1)}$ The insidious disease has a typical latency period of approximately 20 years, ranging from a few months to 30 or more years. ${ }^{(2,3,4)}$ In addition, the International Agency for Research on Cancer (IARC) has recently stated that there is sufficient evidence in humans for the carcinogenicity of beryllium and beryllium compounds. (5)

Because CBD is immunologically-induced, it has been reported that CBD patients may undergo a sensitization process before the appearance of granulomas. ${ }^{(1,6)}$ The blood lymphocyte proliferation test (BLPT) identifies sensitization when a worker has an abnormal lymphocyte proliferation rate. BLPTs have been performed on several thousand current and former employees at RFETS. As of June 1995, the sensitized cases numbered 86 while there were 53 confirmed CBD cases. One CBDcaused death has been reported at RFETS.(2) The percent of sensitized 
cases that evolve to CBD cases is not known, but some experts, admitting uncertainty, report as high as between $50-90 \%$. $^{(2,3,7)}$

Prior to 1984, exposure to beryllium at RFETS was assessed via fixed airhead (FAH) samples, in which a filter cassette was affixed to each of the machines, generally within a few feet of the worker's actual breathing zone (see Figures 1 and 2). Samples were collected daily during operations yielding approximately 500,000 FAH results. In June 1984, the first CBD case was identified at RFETS. One recommendation by an investigation committee was to institute a personal breathing zone (PBZ) monitoring program to assess worker exposures. ${ }^{(8)}$ From 1984-87, industrial hygienists at the plant sampled the breathing zones of workers to estimate airborne beryllium concentrations and evaluate the potential hazard. The simultaneous sampling provides an opportunity to compare the two sampling methods.

The purpose of this study was to evaluate the air sampling results collected at RFETS with the ultimate goal of approximating exposures for a case-control study. Considering a CBD prevalence of greater than $2 \%$ at RFETS, a subsequent case-control study may be helpful in deciding whether the current DOE, ACGIH, and OSHA beryllium limit of $2 \mathrm{ug} / \mathrm{m}^{3}$ provides ample protection. 


\section{METHODS}

Although beryllium was used in at least 36 buildings at RFETS, the majority of the dust-producing work (i.e., machining and polishing) was performed in two adjacent rooms in Building 444.(9) This exposure assessment was limited to these two rooms. Of the 53 CBD cases, 45 either worked with beryllium, or had a job that required their presence, in Building 444 sometime during their employment. ${ }^{(2)}$ Also, most of the available PBZ sampling data were collected in these two rooms.

\section{FAH Time Trend Analysis}

The scope of this exposure assessment included the FAH data from 1970-88. During these years, fifteen machines and three walls in proximity to the machines were sampled routinely in the two rooms generating over 70,000 FAH results. A data set was drawn by randomly selecting the FAH results from two days per month per sampling site.

The resultant sample of $7,455 \mathrm{FAH}$ results was used to calculate annual mean beryllium levels in the two machining rooms. The FAH data were also analyzed for homogeneity between the two rooms over the years.

\section{Comparison of FAH Data to Production Levels and Ventilation}

The FAH results were compared with production levels over similar time periods. The production levels were estimated from the amount of 
beryllium chips removed from the bulk beryllium during machining. The beryllium chips were estimated to be about a half of the total beryllium machined. In addition, the dates of local exhaust ventilation (LEV) changes were used as cut-off dates to determine distinct exposure periods using the Kruskal-Wallis Test based on the ranking of the FAH results. ${ }^{(10)}$

\section{Selection of PBZ Data}

A data set of $162 \mathrm{PBZ}$ samples was generated from the available 1984-87 data. The primary criterion for including the PBZ results in this study was a sample volume of greater than 1.1 cubic meters $\left(\mathrm{m}^{3}\right)$, which corresponded to a sampling period between 6-8 hours (flow rate: 3-4 liters per minute). The highest sample volume was $1.8 \mathrm{~m}^{3}$. The PBZ data were also analyzed for lognormality.

\section{Comparison of FAH and PBZ Data}

To compare the FAH and PBZ data, results were matched by machine number and sampling date/time. A total of 102 matched pairs was found during the period from August 1984 to September 1986. After this later date, the high velocity/low volume local exhaust ventilation (HV/LV LEV) system was installed, reducing practically all PBZ results to the lowest recordable value. Thus, only results before the installation of the HV/LV LEV system were considered useful for the FAH/PBZ comparison.

FAH sampling protocol varied over the FAH/PBZ comparison time period. The data were therefore adjusted as follows: 
1) From August to November 1984, FAH samples were collected over 24 hours. The filter mass result was then divided by eight hours of air volume. This was a conservative exposure estimate, since the day and second shifts were active and only a few people worked on the third shift (i.e., beryllium was generated over at least two shifts). To reduce the bias in the FAH/PBZ comparison, the FAH recorded concentrations were divided by two. These "halved" FAH values were then paired with the breathing zone results.

2) From November 1984 to September 1986, two FAH samples were taken per day. Labeled as either "A.M." or "P.M.", their respective sample periods were approximately 7:30 am - 4:30 pm and 4:30 pm - 7:30 am. These "A.M." and "P.M." sample periods corresponded roughly with the exposures during the day and second shifts, respectively, since relatively little machining was done during the third shift. To make the FAH/PBZ comparison, PBZ samples taken on the day shift were paired with the "A.M." FAH results, The PBZ results taken on the 2nd shift were paired with the "P.M." FAH result. Most of the pairs were from the day shift. Only 16 were from the second shift, and 13 other PBZ results for which the time was not identified were assumed to be from the day shift.

\section{Treatment of Zeros and "Scribed Values"}

One major concern with the FAH data was the recording of the beryllium concentrations as zero in the sample logbook. From January 1970 to June 1984 , the lowest value other than zero recorded in the 
logbook was $0.16 \mathrm{ug} / \mathrm{m}^{3}$. This lowest value, called the "scribed value" in this study, seemed to be determined arbitrarily with questionable correlation to the flame atomic absorption detection limit. Between June 1984 and September 1986, the scribed value was $0.01 \mathrm{ug} / \mathrm{m}^{3}$, which may have been related to the detection limit. In September of 1986, after the HV/LV LEV system was installed, the scribed value was $0.05 \mathrm{ug} / \mathrm{m}^{3}$.

These various scribed values were treated as follows in the analyses: For the FAH time-trend analyses, the scribed value was halved. For example, when the scribed value was $0.16 \mathrm{ug} / \mathrm{m}^{3}$, the zeros were changed to $0.08 \mathrm{ug} / \mathrm{m}^{3}$. Likewise, when the scribed value was $0.01 \mathrm{ug} / \mathrm{m}^{3}$, the zeros were changed to $0.005 \mathrm{ug} / \mathrm{m}^{3}$. The authors believe this method provided the best estimate of the true average beryllium levels in the machining shop.

For comparison of annual average FAH results with production levels, discrete time periods, and homogeneity between rooms, all results less than $0.16 \mathrm{ug} / \mathrm{m}^{3}$ were raised up to this concentration. This provided a method to incorporate the different scribed values over the years and determine the annual average concentrations with results greater than 0.16 $\mathrm{ug} / \mathrm{m}^{3}$. 


\section{RESULTS}

Table I presents the annual average beryllium concentrations for FAH and PBZ sampling by year from 1970-88. Included in the table are the annual amount of beryllium chips produced, the total number of sample data points and the percentage of data points recorded as zero.

In June 1984 the first case of CBD was diagnosed at RFETS. The scribed limit was changed from 0.16 to $0.01 \mathrm{ug} / \mathrm{m}^{3}$ at this time to reflect the actual detection limit. The exposures for 1984 are thus divided into $1984 \mathrm{a}$ and $1984 \mathrm{~b}$ to demonstrate the difference in average FAH results. Also, 1986 was divided into 1986a and 1984b because the HV/LV LEV system was installed as of September 24, 1986 and the scribed limit was changed to $0.05 \mathrm{ug} / \mathrm{m}^{3}$.

The FAH results demonstrate that the early 1970's and mid-1980's appear to be periods of higher exposures. The changes in the annual averages may be explained by differences in production during those years and by modifications in the LEV system.

Figure 3 shows the average annual FAH results and pounds of beryllium chips versus time. The greatest production occurred between 1983-1987. Further, even though the pounds of beryllium chips was unavailable, it was reported that the early 1970's was also a time of extensive beryllium machining. Simple linear regression shows a good correlation between exposure and production $\left(\mathrm{R}^{2}=0.68\right)$. 
Table II describes the production and LEV factors thought to affect airborne levels of beryllium in the shop areas during four exposure periods. The Kruskal-Wallis Rank Test shows the FAH concentrations between the four exposure periods were statistically different $(p$-value $=0.001){ }^{(11)}$ Therefore, the time trend for changes in exposure were related to ventilation control modifications and production changes.

Figure 4 shows the average annual beryllium concentration over time for each of the two rooms in the study. The t-test for differences in annual FAH concentrations between the two rooms demonstrates no statistical difference $(\mathrm{p}$-value $=0.39)$, which supports grouping the machinists in the two rooms into one homogenous exposure group. In addition, the PBZ data between the two rooms are not found to be statistically different ( $p$-value $=0.20)$.

Figure 5 illustrates a scatterplot of the logarithmic values of the 102 matched pairs of $\mathrm{PBZ}$ and FAH data. The simple linear regression indicates no linear correlation $\left(\mathrm{R}^{2}=0.014\right)$. However, the $\mathrm{p}$-value for test of bias equals 0.0001 , meaning that overall the $\mathrm{PBZ}$ results are statistically higher than the FAH results.

Table III provides comparisons of the PBZ and FAH results. The average $\mathrm{PBZ}$ concentration was $1.04 \mathrm{ug} / \mathrm{m}^{3}(95 \% \mathrm{CI}$ : $0.79,1.29)$ while the average FAH concentration was significantly lower at $0.16 \mathrm{ug} / \mathrm{m}^{3}(95 \%$ CI: $0.10,0.22$ ). The median for the PBZ data was $0.64 \mathrm{ug} / \mathrm{m}^{3}$; whereas, the FAH median was $0.06 \mathrm{ug} / \mathrm{m}^{3}$. Figure 6 illustrates the $\log$ distribution of the PBZ data. The Wilk-Shapiro Test of normality reports that the 
distribution was not significantly different than a lognormal distribution with a $\mathrm{p}$-value of 0.22 . Using the $\mathrm{PBZ}$ data during this time period and assuming the lognormal distribution, $85 \%$ of the results were below the OSHA permissible exposure limit of $2 \mathrm{ug} / \mathrm{m}^{3}$.

\section{DISCUSSION}

The preferred method for a retrospective exposure assessment is through personal breathing zone sampling. However, compared to the number of FAH data points, there is a paucity of PBZ results for beryllium machining at RFETS. Ideally, the FAH data would correlate linearly with the PBZ data. Although the PBZ data were on average six to seven times greater than the FAH results from 1984-87, this study indicated that PBZ/FAH data do not correlate on a one-to-one matching.

The matching of the PBZ and FAH results did contain significant uncertainties. When the PBZ/FAH pairs were matched before November 1984, the FAH results were divided by two because only one FAH sample was taken per day over 24 hours while the mass was divided by eight hours. After November 1984 the pairs were matched as either "A.M." or "P.M.". The former method, dividing the FAH value by two, may create a bias towards a lower concentration in the FAH result.

Another point to consider here is that the locations of some of the FAH cassettes were truly not representative of breathing zone exposures. 
A few of the cassettes were installed behind the ventilation system or several feet away from the work area, thus reducing the likelihood of an exposure correlation between the FAH and PBZ data. Further analysis of the data by sample location may improve the correlation.

The average of the PBZ data between August 1984 and September 1986 was $1.04 \mathrm{ug} / \mathrm{m}^{3}$, or about one-half of the PEL. By reviewing the results in Tables II and III, it was seen that this time period did not contain the greatest concentrations. In fact, the period from 1970-74 appears to have the highest exposure. In addition, continued studies indicate that FAH results in the 1960's report similarly higher FAH results than the mid1980's.

The abundance of zeros recorded in the logbook, especially during the 1970's, also reduces the efficacy of this study. The absolute FAH results are not known, but were assumed to be $0.08 \mathrm{ug} / \mathrm{m}^{3}$ during this time period. Considering the poor correlation between the PBZ and FAH matches, the error involved with a few hundreths of a $\mathrm{ug} / \mathrm{m}^{3}$ in the average FAH concentrations may not be comparatively significant.

The FAH and PBZ results between the two rooms indicated that the workers may comprise one homogenous exposure group. Considering that the rooms of the machining shop were connected and the individual machines were close to each other, the exposures may have been remarkably similar for all the machinists. This homogeneity assumption provides support for the categorization of all machinists into exposure groups over the years. 
Although the uncertainties present many questions pertaining to the FAH data, it is easy to accept the conclusion that the beryllium concentrations did vary through the years. Scanning the FAH estimated means in Table I, the differences in the concentrations are apparent. The Kruskal-Wallis Rank Tests illustrated that the FAH concentrations over the years were statistically different as the cut-off dates for the tests were defined by different LEV system installations and changes in production. It would seem logical to categorize workers into different exposure groups depending on the dates in which they worked in the beryllium machining shop.

\section{CONCLUSION}

The ongoing beryllium health surveillance program at RFETS has identified over fifty cases of chronic beryllium disease in former and current workers. Many of these CBD cases worked in the two primary beryllium machining rooms. The PBZ data indicated that workers in these rooms were at least intermittently exposed to concentrations of beryllium greater than $2 \mathrm{ug} / \mathrm{m}^{3}$. In addition, using the FAH results as a guide, the time period in which the PBZ data was collected may not be indicative of when the exposures were the greatest. The FAH data indicate that concentrations did change over the years. The different annual average 
concentrations were primarily a function of the LEV system and production changes.

Although there are uncertainties, this study provides the best estimate of exposures for many of these cases to date. The results may be used for a semi-quantitative exposure assessment in an ongoing epidemiological study to help understand the etiology and exposure requirements for $\mathrm{CBD}$. 


\section{References}

1. Agency for Toxic Substances and Disease Registry (ATSDR): Updated Toxicological Profile for Beryllium. TP-9204. April 1993.

2. Stange, A.W.: [Personal communication] EG\&G, Rocky Flats, Golden, CO 80402. June 1994/March 1995.

3. Hilmas, D.E.: [Personal communication] EG\&G at Rocky Flats, Golden, CO, 80402. June 1994.

4. Furman, F.J., D.E. Hilmas, and A.W. Stange: Presentation given at the Conference on Beryllium-Related Diseases at Research Triangle Park, N.C., November 9, 1994.

5. International Agency for Research on Cancer: IARC Monographs on the Evaluation of Carcinogenic Risks to Humans, Vol. 58, 1993.

6. Kreiss, K., M.M. Mroz, B. Zhen, J.W. Martyny, and L.S. Newmann: Epidemiology of Beryllium Sensitization and Disease in Nuclear Workers, Am. Rev. of Resp. Dis., Vol. 148,: pp. 985-991 (1993).

7. Newmann, L.S.: [Personal communication] National Jewish Center for Immunology and Respiratory Medicine, Denver, CO, 80206. June 1994.

8. United States Department of Energy: Investigation Report: Beryllium Disease Case at Rocky Flats Plant, Golden, CO, October 1984.

9. Holwager, L.A.: EG\&G in-house report on beryllium usage at Rocky Flats, Golden, CO, May 1994.

10. Neter, J., Wasserman and W., Kutner, M.H., Applied Linear Statistical Models: Regression, Analysis of Variance, and Experimental Designs. 3rd ed., Richard D. Irwin, Inc., 1990, pp. 642-647. 
TABLE I. Fixed Airhead and Breathing Zone Annual Mean Beryllium Results (1970-1988)

\begin{tabular}{|c|c|c|c|c|c|c|}
\hline \multicolumn{7}{|c|}{ Fixed Airhead } \\
\hline Year & $\begin{array}{l}\text { Be } \\
\text { Chips } \\
\text { (lbs.) }\end{array}$ & $\begin{array}{l}\text { \# of } \\
\text { Data } \\
\text { Pts. }\end{array}$ & $\begin{array}{l}\% \text { Data } \\
\text { Zero }\end{array}$ & $\begin{array}{c}\text { Est. Mean } \\
\mathrm{ug} / \mathrm{m}^{3}\end{array}$ & $\begin{array}{l}\text { \# of } \\
\text { Data } \\
\text { Pts. }\end{array}$ & $\begin{array}{c}\text { Est. Mean } \\
\mathrm{ug} / \mathrm{m}^{3}\end{array}$ \\
\hline $\begin{array}{l}1970 \\
1971 \\
1972 \\
1973 \\
1974 \\
1975 \\
1976 \\
1977 \\
1978 \\
1979 \\
1980 \\
1981 \\
1982 \\
1983 \\
1984 \mathrm{a} \\
1984 \mathrm{~b} \\
1985 \\
1986 \mathrm{a} \\
1986 \mathrm{~b} \\
1987 \\
1988\end{array}$ & $\begin{array}{c}\cdot \\
\dot{\cdot} \\
\dot{.} \\
\dot{.} \\
500 \\
518 \\
1550 \\
2224 \\
2064 \\
4609 \\
5356 \\
5278 \\
4354 \\
4430 \\
2266\end{array}$ & $\begin{array}{c}308 \\
402 \\
430 \\
430 \\
416 \\
432 \\
431 \\
432 \\
431 \\
369 \\
410 \\
426 \\
432 \\
432 \\
180 \\
243 \\
396 \\
242 \\
48 \\
255 \\
310\end{array}$ & $\begin{array}{c}63.63 \\
62.18 \\
59.53 \\
50.93 \\
69.47 \\
85.87 \\
95.82 \\
91.88 \\
96.28 \\
90.51 \\
87.07 \\
83.56 \\
87.03 \\
58.79 \\
54.44 \\
10.28 \\
7.32 \\
1.65 \\
0 \\
0 \\
0\end{array}$ & $\begin{array}{l}0.306 \\
0.358 \\
0.358 \\
0.416 \\
0.228 \\
0.162 \\
0.105 \\
0.121 \\
0.134 \\
0.102 \\
0.156 \\
0.137 \\
0.163 \\
0.271 \\
0.304 \\
0.158 \\
0.163 \\
0.159 \\
0.039 \\
0.034 \\
0.045\end{array}$ & $\begin{array}{l}\cdot \\
\dot{ } \\
. \\
. \\
. \\
. \\
. \\
. \\
. \\
. \\
. \\
. \\
. \\
33 \\
51 \\
33 \\
29 \\
16 \\
.\end{array}$ & $\begin{array}{c}. \\
. \\
. \\
. \\
. \\
. \\
. \\
. \\
. \\
. \\
. \\
. \\
1.092 \\
1.195 \\
0.779 \\
0.092 \\
0.189\end{array}$ \\
\hline
\end{tabular}

- No data available

* After 1984, zeros were no longer recorded. Instead, the scribed value was used. 
TABLE II. Significantly Different Exposure Periods at the Rocky Flats Beryllium Machining Shop

\begin{tabular}{ccc}
\hline $\begin{array}{c}\text { Exposure } \\
\text { Period }\end{array}$ & $\begin{array}{c}\text { \# of FAH } \\
\text { Data Pts. }\end{array}$ & $\begin{array}{c}\text { Events Relevant to } \\
\text { Exposure Levels }\end{array}$ \\
\hline $1 / 70-12 / 74$ & 1986 & $\begin{array}{c}\text { Period of high production with } \\
\text { original centralized LEV system }\end{array}$ \\
$1 / 75-12 / 82$ & 3363 & $\begin{array}{c}\text { Near } 1 / 75, \text { production decreased and } \\
\text { LEV system was modified }\end{array}$ \\
$1 / 83-9 / 86$ & 1493 & Production increased with same LEV system \\
$10 / 86-12 / 88$ & 613 & $\begin{array}{c}\text { Production began to decrease and new } \\
\text { HV/LV LEV system installed on } 9 / 24 / 86\end{array}$ \\
\hline
\end{tabular}

Kruskal-Wallis Rank Test (Chi-Square Approximation):

$\mathrm{CHISQ}=772.37 \quad \mathrm{DF}=4 \quad$ Prob $<0.0001$

$\mathrm{P}$-value $<0.001$ for all pairwise exposure period comparisons 
TABLE III. 1984-86 Breathing Zone vs. Fixed Airhead Sampling Data

\begin{tabular}{cc}
\hline Breathing Zone & Fixed Airhead \\
\hline $\mathrm{N}=102$ & $\mathrm{~N}=102$ \\
Mean $=1.04 \mathrm{ug} / \mathrm{m}^{3}$ & Mean $=0.16 \mathrm{ug} / \mathrm{m}^{3}$ \\
Std Dev $=1.25$ & Std Dev $=0.33$ \\
$95 \%$ Confidence Interval & $95 \%$ Confidence Interval \\
$(0.79,1.29)$ & $(0.10,0.22)$ \\
$99 \%=5.75^{*}$ & $99 \%=1.22^{*}$ \\
$95 \%=3.3$ & $95 \%=0.41$ \\
$90 \%=2.06$ & $90 \%=0.29$ \\
$10 \%=0.11$ & $10 \%=0.01$ \\
$5 \%=0.07$ & $5 \%=0.01$ \\
$1 \%=0.02$ & $1 \%=0.01$ \\
Median $=0.64$ & Median $=0.06$ \\
* Results Below $2 \mathrm{ug} / \mathrm{m}^{3}=85 \%$ & $\%$ Results Below $2 \mathrm{ug} / \mathrm{m}^{3}>99 \%$ \\
\hline Assuming lognormality &
\end{tabular}


FIGURE 1. Bridge Port Mill: (above) Used for small machining and drilling. Pen points to fixed airhead sampler that is within a few feet of the worker's breathing zone. This FAH was part of the exposure assessment.

FIGURE 2. Heller Saw: (below) Cut beryllium for initial processing. Pen points to fixed airhead sampler that appears to be above the hood, thereby reducing its efficacy. This FAH was not part of the exposure assessment, but it did record high concentrations especially in the early 1970 's.

FIGURE 3. FAH results and production levels over time

FIGURE 4. Comparison of beryllium FAH data for rooms 106 and 107

FIGURE 5. Matched pairs of PBZ versus FAH beryllium results

FIGURE 6. Distribution of PBZ data 

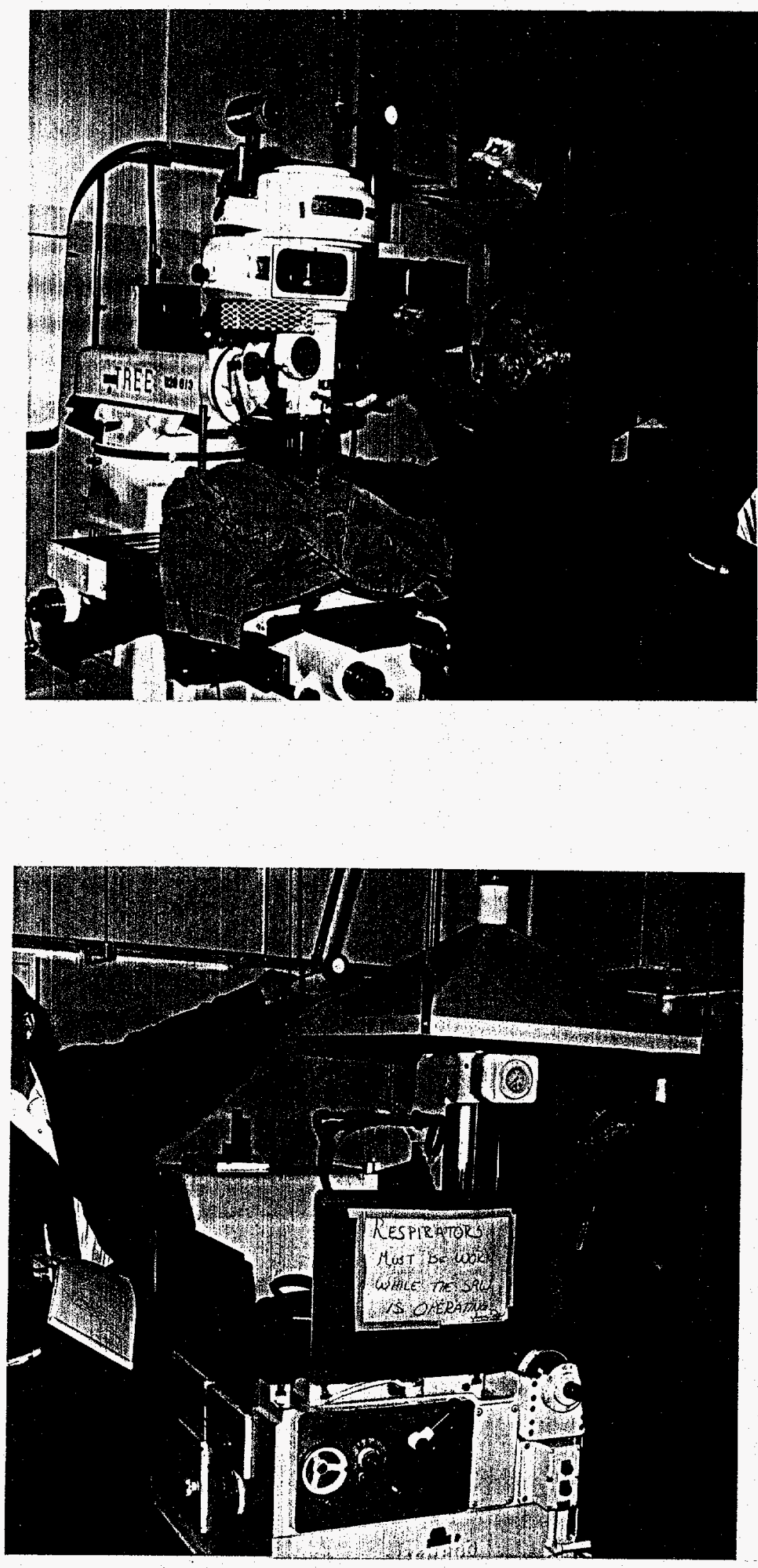


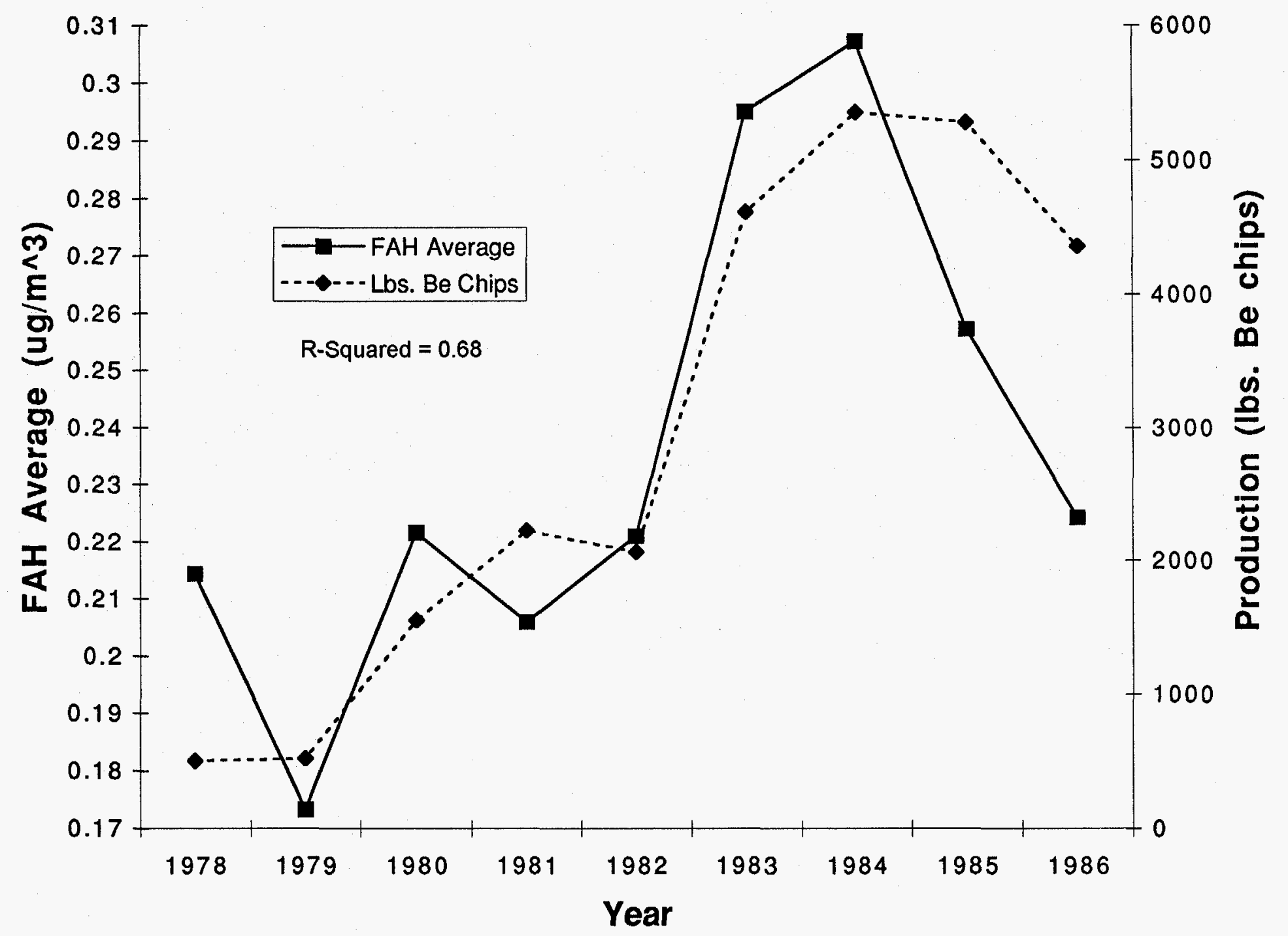




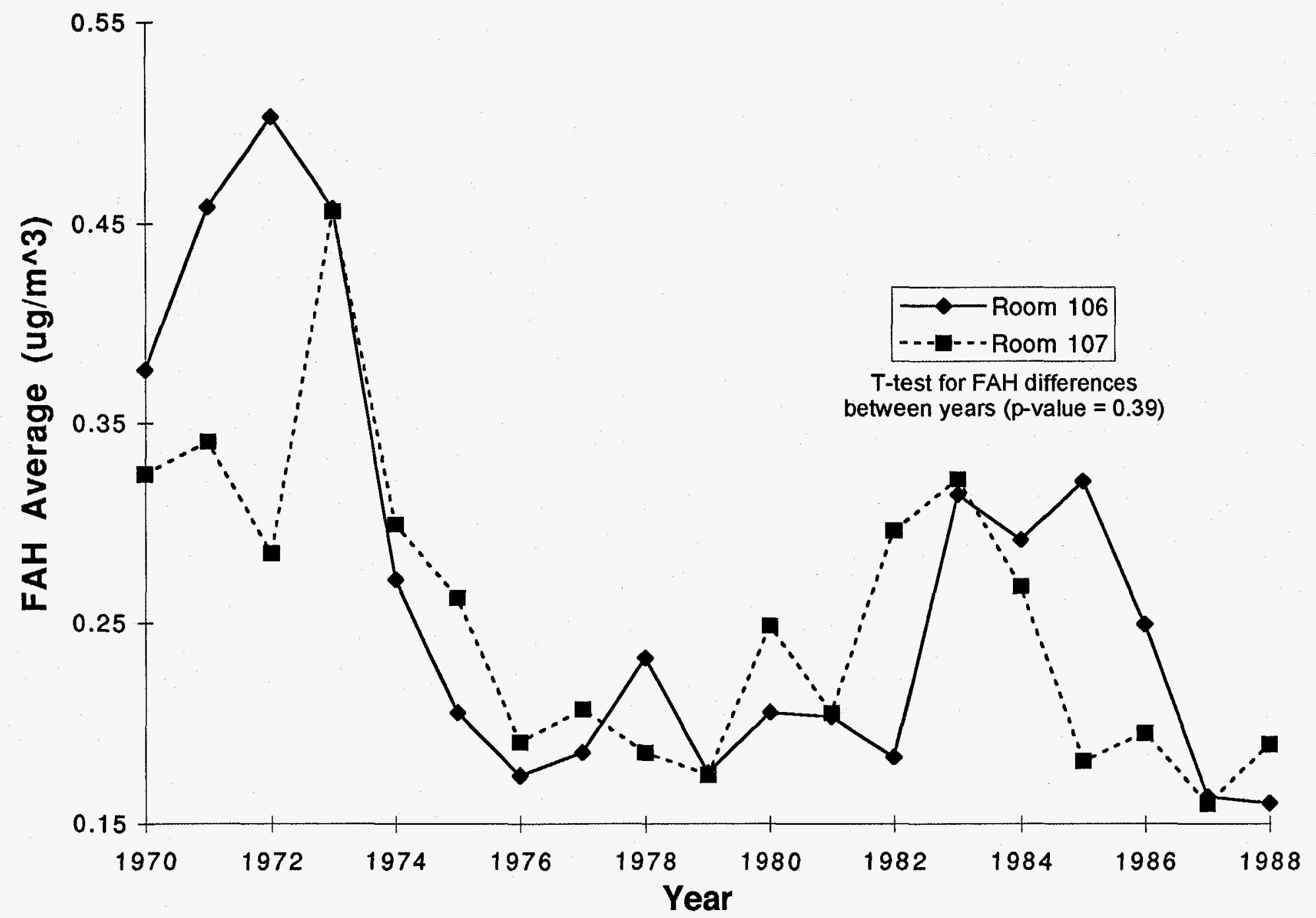




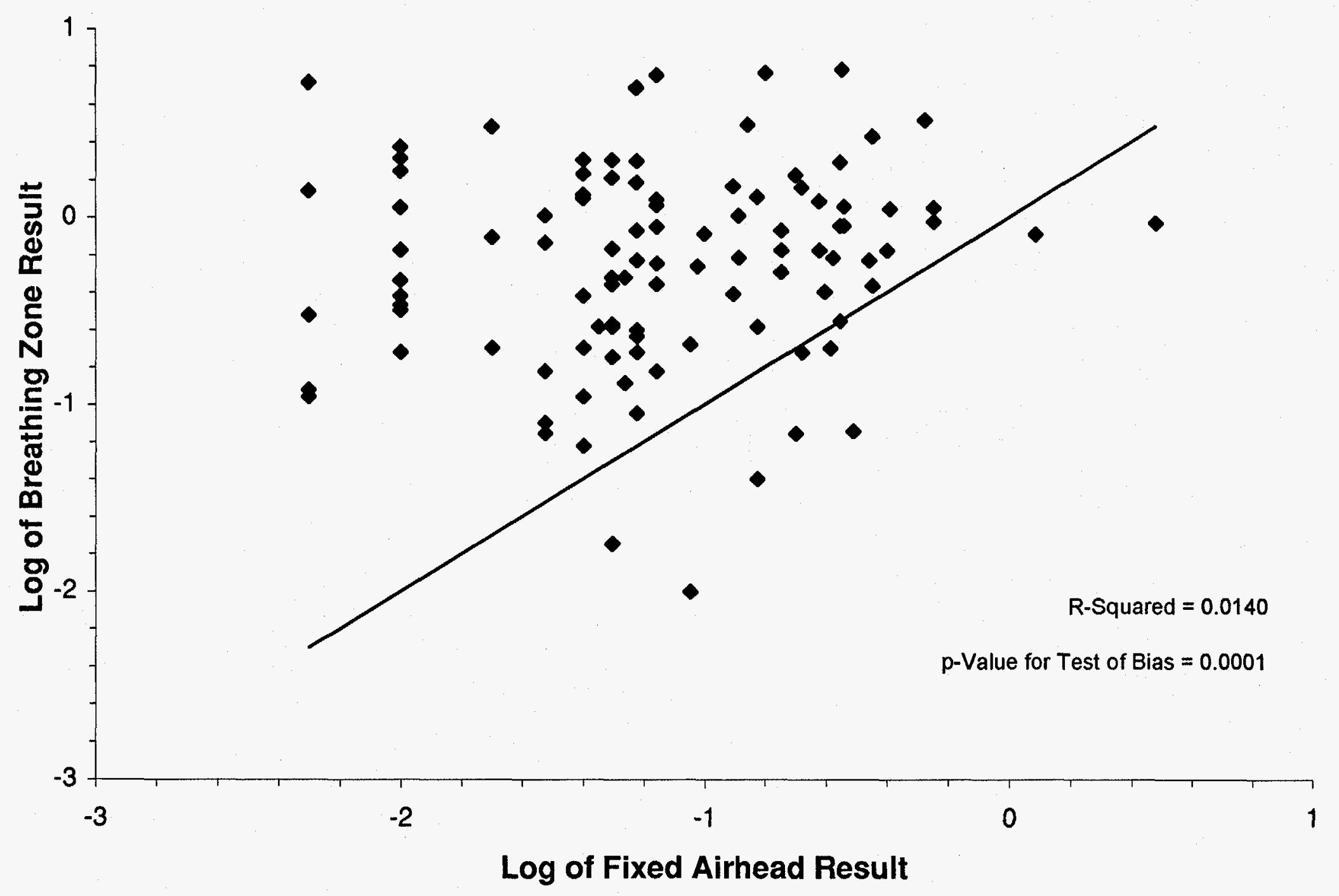




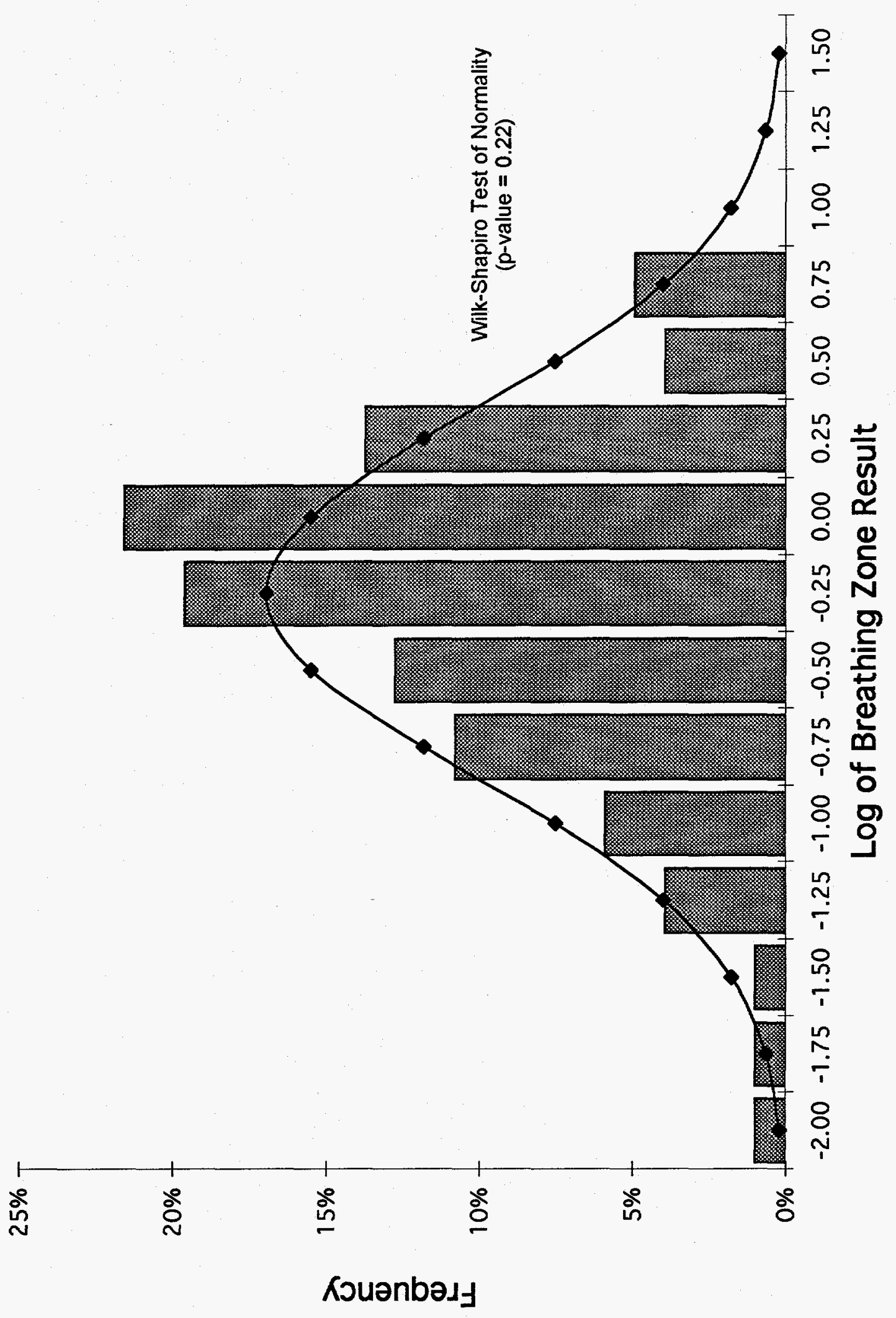

